\title{
Mudanças climáticas e a tarefa dos ecossocialistas: pelo abandono do voluntarismo geológico *
}

\author{
Eduardo Sá Barreto **, ***
}

\begin{abstract}
Resumo
$\mathrm{O}$ artigo se lança à difícil tarefa de realizar uma dura crítica interna. Diante do conhecimento disponível sobre as mudanças climáticas, o campo marxista tem demonstrado profunda reticência em soar o alarme do risco existencial. Essa paralisia traduz-se na reprodução de uma práxis pulverizada, enrijecida, pouco ambiciosa e que se satisfaz com sucessos parciais e pequenos avanços. Argumenta-se ao longo do texto que mesmo essa concepção modesta de "sucesso parcial" ou "pequenos avanços" é insustentável no quadro geral dos desafios climáticos diante da humanidade. Para construir o raciocínio, estabeleço três pontos de diálogo com os posicionamentos dos ecossocialistas: (i) a vocação espontaneamente emancipatória e ecológica das lutas populares, (ii) o potencial transformador do acúmulo sistemático de pequenos avanços e reformas e (iii) a possibilidade de "ganhar tempo" via pequenos avanços e reformas. Por fim, a última seção aborda o perigo do efeito desmobilizador diante do reconhecimento explícito das transformações climáticas que afetarão dramaticamente a humanidade nas próximas décadas.
\end{abstract}

Palavras-chave: Mudanças climáticas, Ecossocialismo, Reformas.

\section{Abstract}

\section{Climate change and the role of ecosocialists: the abandonment of geological voluntarism}

The article sets out the difficult task of performing a rigorous internal critique. Given the available knowledge about climate change, the Marxist tradition has been deeply reluctant to sound the alarm of existential threat. This paralysis translates into the reproduction of a pulverized, inflexible, and unambitious praxis that is satisfied with partial successes and small breakthroughs. I argue throughout the text that even this modest conception of "partial success" or "small breakthroughs" is unsustainable considering the overall picture of the climate challenges facing humanity. To construct the reasoning, I establish three points of dialogue with my fellow ecosocialists: (i) the spontaneously emancipatory and ecological leaning of popular struggles; (ii) the transformative potential of systematic accumulation of small advances and reforms; and (iii) the possibility to buy "time" through small advances and reforms. Finally, the fourth section addresses the danger of the demobilizing effect in the face of the explicit knowledge that ongoing climate change will dramatically affect humankind in the coming decades.

Keywords: Climate change, Ecosocialism, Reform.

JEL B51, Q0, P1.

Há pouco mais de 10 anos, duas emblemáticas publicações traçavam projeções ambiciosas de mitigação de gases de efeito estufa (especialmente o $\mathrm{CO}_{2}$ ) para estabilizar sua concentração na atmosfera e impedir um aumento da temperatura média do planeta (relativa ao ano-base de 1750) acima de $2^{\circ} \mathrm{C}$ até o fim do século XXI (IPCC, 2007; Stern, 2007). Mesmo havendo diferenças entre as recomendações da Fourth Assessment Report (AR4) e as da Stern Review (comissionada pelo

\footnotetext{
${ }^{*}$ Artigo recebido em 8 de abril de 2019 e aprovado em 18 de maio de 2020.

** Professor da Faculdade de Economia da Universidade Federal Fluminense, Niterói, RJ, Brasil. E-mail: eduardobarreto@id.uff.br. ORCiD: https://orcid.org/0000-0003-4431-2607.

${ }^{* * *}$ Pesquisador do Núcleo Interdisciplinar de Estudos e Pesquisas sobre Marx e o Marxismo da Universidade Federal Fluminense (NIEP-Marx/UFF), Niterói, RJ, Brasil.
} 
governo do Reino Unido), ambas apresentavam exigências de reduções anuais, sistemáticas e sustentadas dos níveis totais de emissões antropogênicas. Nesses 10 anos, o retumbante fracasso em até mesmo conter a trajetória crescente dessas emissões poderia levar o observador menos atento a concluir que nada se fez no sentido de atender às recomendações. No entanto - e a despeito da notável lentidão política observada nas convenções climáticas promovidas pela $\mathrm{ONU}$-, tal conclusão não seria rigorosamente correta.

Em trabalho anterior, apresentei longo inventário de uma série de políticas climáticas nacionais, várias delas aderentes às medidas propostas (especialmente as do IPCC, mais exigentes) e algumas delas já em estágio avançado em termos de implementação, consolidação e operação. Quanto aos resultados esperados, contudo, os impactos foram menos que expressivos (Sá Barreto, 2018). Não é o caso de reprisar, neste trabalho, os argumentos teóricos para demonstrar as raízes dinâmicas desse fracasso geral. Esta brevíssima recuperação tem o objetivo de apenas sublinhar quatro coisas: primeiro, o diagnóstico de uma década atrás já era grave o suficiente para convocar as sociedades do mundo à ação; segundo, já não era trivial, à época, o conjunto de medidas envolvidas nessa ação; terceiro, mesmo dentro de certos limites (e aquém do prescrito), observou-se uma pletora de políticas e mobilizações populares direcionadas à mitigação de emissões; quarto, apesar disso, sequer se interrompeu a tendência geral de crescimento das emissões totais.

Admitindo um cenário com esses contornos, já seria causa para alarme constatar que, em 2019, nada avançamos. O cenário, contudo, não permaneceu o mesmo. Por um lado, os processos concretos de mudança climática vêm recorrentemente superando as piores projeções da época. Isso se manifesta claramente na calibragem do entendimento científico e da linguagem empregados na Fifth Assessment Report (AR5). A título de exemplo, passa-se a admitir explicitamente a possibilidade de mudança climática abrupta ${ }^{1}$ (ausente nos relatórios anteriores) e acrescenta-se, ao lado dos esforços de mitigação, a necessidade de emprego em larga escala e escopo de tecnologias de extração de carbono da atmosfera (IPCC, 2014). Por outro lado, a avaliação sobre o horizonte temporal para ação encolheu consideravelmente, como demonstram estudos de 2018.

Ao longo desse ano, a publicação de uma série de relatórios climáticos trouxe uma elevação marcante do tom de alarme da comunidade científica em relação aos desafios iminentes à sobrevivência humana diante das transformações profundas e aceleradas pelas quais passa nosso planeta $^{2}$. A própria veiculação (mesmo que incipiente) de uma noção de risco existencial à nossa espécie é um fato novo que simboliza os entendimentos mais recentes. Cada vez menos se fala em 2100 como horizonte temporal de referência. Cada vez mais se fala em 2050 e 2030, mesmo nas publicações mais conservadoras ${ }^{3}$.

Diante disso, o campo marxista tem demonstrado uma paralisia teórica e ausência de ambição prática notáveis. Pretendo, neste trabalho, demonstrar a exigência de reconfigurar imediatamente a maneira como avaliamos a (e atuamos na) emergência climática já em curso. Para tal, dialogo

(1) "Mudança climática abrupta refere-se a mudança de grande escala no sistema climático que transcorre ao longo de poucas décadas ou menos, persiste [...] no mínimo por algumas décadas e causa disrupções substanciais em sistemas humanos e naturais" (IPCC, 2014, p. 118).

(2) Cf. IPCC (2018), Steffen et al. (2018) e USGCRP (2018).

(3) Conservadoras em um sentido de divulgação científica. Essa questão será retomada na terceira seção. 
criticamente com três características peculiares do pensamento ecossocialista. Na primeira seção, criticamos a noção postulada de que as lutas da classe trabalhadora têm uma vocação emancipatória espontânea e que essa vocação traduz-se, também direta e espontaneamente, em mobilização de caráter ecológico. Na segunda seção, abordamos uma das alegações frequentes para defender a reprodução indefinida de uma luta pulverizada, de pretensões imediatas e modestas: a do acúmulo progressivo de resultados até uma transformação qualitativa substancial. Na terceira seção, abordamos outra dessas alegações: a de que essa luta no varejo e pouco ambiciosa, ao menos garante alguns resultados momentâneos e mantem a base mobilizada, permitindo ganhar tempo até que se reúnam as condições necessárias para uma luta efetivamente disruptiva. Feita a crítica, procuro abordar, na quarta seção, uma objeção legítima que pode ser endereçada à minha reflexão: o caráter potencialmente desmobilizador de um diagnóstico agudamente sombrio, que delineia um campo estreitíssimo de alternativas. A última seção conclui o trabalho.

\section{0 problema da finalidade e dos meios adequados}

[N]ão existe potência de fazer coisas opostas ao mesmo tempo [...] (Aristóteles, 2002, p. 409).

Segundo Löwy (2005, p. 18-19), o pensamento ecossocialista apoia-se em dois pilares fundamentais: em primeiro lugar, o reconhecimento da impossibilidade de replicar as sociedades ocidentais afluentes para todo o planeta sem causar, no processo, grandes crises ambientais; em segundo lugar, o reconhecimento de que, mesmo não estendendo a afluência de um seleto grupo de países, a continuação da civilização baseada na economia de mercado ameaça a vida humana, no médio prazo.

Neste momento, importa apenas sublinhar que há uma explícita admissão da inviabilidade ecológica da sociedade capitalista e de que, portanto, ao menos no médio prazo, sua superação é imprescindível. Isso apenas demonstra algo que o leitor certamente já sabia: o diagnóstico ecossocialista se desdobra necessariamente na posição de uma clara finalidade: a ruptura histórica com a lógica do capital e todo o modo de produção e vida que a ela corresponde ${ }^{4}$. Todo o resto, então, deve passar a ser uma discussão dos meios adequados para a efetivação deste fim.

Naturalmente, se tratamos de um conjunto de concepções vinculado a uma tradição materialista, nenhum curso de transformação social efetiva poderia ser buscado sem contato com o agir concreto dos seres humanos e dos conflitos travados pelas classes no tecido social. Tal postura intelectual e prática se encontra em perfeita consonância com o enunciado marxiano de que são os seres humanos que fazem sua história. No entanto, resta lembrar seu complemento, o de que não a fazem sob condições por eles escolhidas. A discussão dessas condições será realizada em maior detalhe na terceira seção. Por ora, pensemos na primeira parte desse enunciado à luz de um outro insight de Marx: o de que por meio de nosso agir, produzimos formas sociais e reproduzimos estruturas sem que isso seja apreendido diretamente pela consciência e sem que isso figure

(4) Em texto mais recente, Löwy (2018, p. 162) declara com todas as letras: "Precisamos acabar com o capitalismo antes que ele acabe conosco!"’. 
necessariamente como finalidade do agir - o famoso "Eles não sabem disso, mas o fazem" (Marx, 2013, p. 149).

É predominante entre marxistas a leitura de que a classe trabalhadora é, por excelência, o sujeito histórico da superação do capitalismo. A vocação da classe trabalhadora em seu "fazer história" seria, portanto, trazer abaixo a vida presidida pelo capital. Tal leitura encontra, inclusive, vasto apoio textual na obra de Marx e, expressa nesses termos, convirjo para ela. O problema aparece, porém, quando se agregam postulados ad hoc a essa formulação geral.

Segundo Burkett (1999, p. 215-216),

A posição dos trabalhadores em relação ao valor de uso e à natureza é bem diferente. Sua separação social dos meios necessários de produção, e sua necessidade de valores de uso para sobreviver e se desenvolver como seres humanos, imbui as atividades de intercâmbio e produção dos trabalhadores com um imperativo não-instrumental quanto ao valor de uso que não existe no caso do capital. Os trabalhadores vendem sua força de trabalho e participam da produção para não acumular valor, mas para obter valores de uso. [...] Os trabalhadores são tanto forças naturais quanto sociais; eles têm uma substância natural e se desenvolvem como seres humanos apenas em e através de uma constante ligação com a natureza e a sociedade. Segue-se que, para o trabalho, a riqueza da natureza não é um mero insumo em uma função de produção cujo produto é o ser humano, mas sim a própria substância do desenvolvimento humano - o "corpo real" do trabalho, como Marx coloca no Grundrisse. Segue-se também que o trabalho não compartilha o necessário antagonismo do capital em relação à natureza. [...] A relação não-instrumental do trabalho com a natureza corresponde, pelo menos em princípio, ao tipo de valoração da natureza como um fim em si, que é necessário para uma apropriação sustentável e voltada ao desenvolvimento humano [human-developmental] das condições naturais.

A passagem de Burkett, pensador merecidamente prestigiado de nosso campo, é infelizmente uma constelação de erros. Sim, a relação dos trabalhadores com a natureza é distinta da relação do capital com a natureza, mas apenas na medida em que ela é instrumental para fins diferentes em cada um dos casos. Para o capital, é meio material para seu movimento de expansão, é sorvedouro dos rejeitos de sua atividade e (pensando na natureza sistemicamente) é campo que proporciona novas necessidades para o capital explorar ${ }^{5}$. Para o trabalhador, é fonte dos valores de uso que sustentam sua vida, que habilitam o seu desenvolvimento e o gozo de seu (escasso) tempo livre. A partir de um ponto de vista ecológico, não surpreende que esses fins sejam hierarquizados de tal modo que os do capital apareçam como reprováveis e indesejáveis (o que, de fato, são) e os dos trabalhadores apareçam como fins melhores. Todavia, daí não segue automaticamente que esses fins sejam perseguidos de maneira não-instrumental, nem que sejam diretamente compatíveis com qualquer noção de sustentabilidade ecológica. Lembremos, para consolidar este ponto, o que diz Marx (2011, p. 334) sobre a relação que se estabelece entre seres humanos e natureza sob o domínio do capital:

(5) Basta lembrar, por exemplo, da seguinte afirmação de Marx: “A pátria do capital não é [...] a fertilidade absoluta do solo, mas sua diferenciação, a diversidade de seus produtos naturais é que constitui o fundamento natural da divisão social do trabalho e incita o homem, pela variação das condições naturais em que ele vive, à diversificação de suas próprias necessidades, capacidades, meios de trabalho e modos de trabalhar. É a necessidade de controlar socialmente uma força natural, de poupá-la, de apropriar-se dela ou dominá-la em grande escala mediante obras feitas pela mão do homem o que desempenha o papel mais decisivo na história da indústria" (Marx, 2013, p. 582). 
Daí a grande influência civilizadora do Capital [...]. Só então a natureza torna-se puro objeto para o homem, pura coisa da utilidade; deixa de ser reconhecida como poder em si; e o próprio conhecimento teórico das suas leis autônomas aparece unicamente como ardil para submetê-la às necessidades humanas, seja como objeto do consumo, seja como meio da produção.

Para reforçar, se admitimos que a dinâmica do capital imprime na realidade essa fissão ${ }^{6}$ entre sociedade e natureza, os indivíduos podem (e de fato irão) estabelecer com esse objeto externo uma relação de apropriação em benefício privado, i.e., uma relação instrumental ${ }^{7}$.

Burkett reforça seu postulado de não-instrumentalidade afirmando que o trabalhador se desenvolve como ser humano apenas por meio de seu constante emaranhamento com a natureza e a sociedade. A afirmação geral dos pressupostos materiais naturais do desenvolvimento humano é absolutamente correta, mas não segue daí que esses requisitos dizem respeito apenas à classe trabalhadora e tampouco se deriva necessariamente disso nenhum caráter qualitativo específico da relação que se estabelece entre trabalhadores e natureza. Especialmente importante para os objetivos deste artigo, é mais gravemente indevido saltar à conclusão de que essa relação possui um caráter essencialmente ecológico - i.e. de coevolução sustentável entre sociedade e natureza -, como faz o autor ao final do trecho citado acima.

O argumento elaborado por Burkett - não apenas no trecho citado, mas em todo o capítulo do qual ele foi extraído - omite um determinante central e historicamente específico da vida em sociedade regida pelo capital. Qualquer relação que os trabalhadores venham a estabelecer com seus pressupostos materiais naturais é, nesta sociedade, necessariamente mediada pela relação que estabelecem com o próprio trabalho e, mais concretamente, com o trabalho assalariado (Postone, 2003). E essa centralidade do trabalho como a categoria mediadora central da vida humana no capitalismo se expressa claramente nas formas concretas que assumem as lutas dos trabalhadores.

É impossível cotejar exaustivamente o conteúdo dessas lutas no espaço de uma seção. Mas se quisermos encontrar um núcleo histórico suficientemente representativo, podemos pensar em dois níveis de incidência, um mais imediato e um mais geral. No nível mais imediato, encontramos lutas por melhores salários, condições menos insalubres de trabalho, menores jornadas, férias e licenças remuneradas etc. No nível mais geral, encontram-se demandas que, no curso do século XX, tornaramse símbolos de um pequeno conjunto de Estados de bem-estar social que se consolidaram no período do pós-guerra: garantia do (pleno) emprego, saúde, educação e previdência universais e uma série de outros direitos que conformam uma rede de proteção social.

É possível afirmar que, em ambos os níveis, o atendimento dessas demandas exige a reprodução saudável do capital e de sua lógica. No plano imediato, melhores salários e remuneração por tempo de não-trabalho envolvem deduções diretas sobre o mais-valor criado. Condições menos insalubres de trabalho exigem frequentemente adiantamentos mais volumosos de capital constante, reconfigurando as condições de competitividade vigentes em um determinado setor (e desse setor no plano nacional em relação aos concorrentes internacionais). Menor jornada de trabalho implica

(6) Temos aqui uma referência indireta à falha metabólica. Para mais detalhes, cf. Foster (2005) e sua discussão rigorosa tanto das evidências concretas para a categoria quanto da sua base textual na obra de Marx.

(7) Estou, neste trecho, parafraseando Medeiros (2013) e sua discussão da crítica que Marx e Engels (2007) dirigem às teorias da utilidade em A ideologia alemã. 
restrição do consumo da força de trabalho e, portanto, restrição da atividade criadora de mais-valor. Não reste dúvida de que é possível obter e defender todas essas vitórias. É preciso admitir, porém, que todas elas pressupõem uma reprodução tanto mais vigorosa do capital.

O mesmo ocorre, em escala ampliada, quando passamos ao plano geral. A sustentação do pleno emprego exige uma dinâmica de criação de postos de trabalho capaz de compensar o (des)equilíbrio entre a tendência repulsora de força de trabalho oriunda do avanço das forças produtivas e a expansão da população apta a trabalhar. Isso, por seu turno, pressupõe o crescimento da economia nacional em um ritmo mínimo determinado. $\mathrm{O}$ mesmo resultado se encontra quando olhamos os requisitos para a sustentação de uma rede de proteção social. Sua manutenção (e eventual expansão) exige uma mobilização de recursos por parte do Estado que têm origem em tributação e em processos de endividamento público. O sistema como um todo será tão mais sustentável quanto mais for baseado em receitas obtidas via tributos. Esse volume de receitas será tão mais expressivo quanto mais intensa e abrangente for a atividade econômica.

Mais uma vez, esse comentário não pretende em momento nenhum questionar as possibilidades de sucesso dessas lutas. As mediações apontadas, contudo, são suficientes para desdobrar uma implicação crucial: as lutas trabalhistas tradicionais estão voltadas a fins que exigem que a classe trabalhadora se volte à (de maneira direta ou indireta) promoção do capital atuando nacionalmente e do crescimento econômico nacional.

Dois elos postulados pelos ecossocialistas se encontram questionados nesse momento: o caráter imediatamente emancipatório das lutas concretas dos trabalhadores e a vocação imediatamente ecológica dessas lutas. Se é possível demonstrar que a lógica do capital e o seu desenvolvimento histórico concreto são profundamente antiecológicos, então qualquer agir que se volte, por força de suas finalidades, à reprodução dessa lógica, compartilha dessa natureza destrutiva.

Mais que isso, é ainda possível sustentar que esse entrelaçamento entre condições materiais e sociais da vida dos trabalhadores, sua pauta de reivindicações e os meios exigidos para sua realização opera no sentido de produzir, paulatinamente, uma moral conservadora, não emancipatória. Segundo Medeiros e Sá Barreto (2013, p. 324), é porque a atividade humana consciente é "destinada a realizar uma finalidade previamente definida que não apenas essa finalidade emerge como guia diretriz de todo o processo de objetivação (como ética) mas como a base do comportamento de quem trabalha (como moral) e como critério para julgar a adequação da prática (juízo de valor)”. Invertendo a equação, práticas disruptivas que desestabilizam a economia nacional, colocando sob risco as possibilidades de emprego e renda, a capacidade fiscal do Estado e, no limite, os direitos a certos serviços gratuitos, tendem a ser ajuizadas negativamente, evitadas, rejeitadas.

Não surpreende, por isso, a frequência com que o discurso ecossocialista, diante de requerimentos ecológicos claramente antagônicos à reprodução minimamente saudável do capital, precisa entregar-se a malabarismos para "demonstrar" que a efetivação de suas proposições pode ser feita simultaneamente à expansão do emprego. Williams (2010, p. 155; ênfase adicionada), mas não apenas ele, exibe claramente essa tensão insanável quando celebra que, uma "renovada ênfase em energia alternativa e na infraestrutura para sustenta-la teria o efeito benéfico adicional de nos tornar não só livres de carbono em 2050, mas também de criar milhões de novos empregos altamente qualificados". Sublinha ainda que qualquer "movimento ecológico que se desenvolva precisa 
necessariamente argumentar que não se trata de sacrifício, mas de melhorar vidas e criar empregos" (Williams, 2010, p. 167; ênfase adicionada).

$\mathrm{Na}$ medida em que se enreda nessas fórmulas tradicionais, o pensamento ecossocialista e as lutas ecológicas correm o risco de converter sua finalidade originária em mera finalidade nominal. Tal como insinua a epígrafe desta seção, não há como realizar a construção de uma sociedade póscapitalista, organizada em torno de parâmetros ecológicos para uma coevolução sustentável entre sociedade e natureza, vinculando-se acriticamente às pautas das lutas trabalhistas em sua configuração corrente, que demandam dos indivíduos adesão à reprodução da sociedade vigente, irremediavelmente antiecológica e destrutiva.

É indevida, portanto, a expectativa assim formulada por Burkett (1999, p. 203):

Uma vez que se abandona a concepção estritamente industrialista de produção e luta de classes, torna-se claro que todas as lutas populares autoativadas sobre condições sociais existentes, e para novas condições compatíveis com um desenvolvimento humano menos restrito, integram o movimento geral em direção a uma forma associada de produção concebida como uma nova união dos produtores com as condições sociais de sua produção.

Indevida porque, em primeiro lugar, nem toda luta é luta da classe trabalhadora. Em segundo lugar, porque nem toda luta da classe trabalhadora é portadora de potencial emancipador. Em terceiro lugar, porque mesmo abstraindo da "concepção industrialista" e assumindo pretensões emancipatórias, nem toda luta é portadora de finalidades realizáveis. Por fim, porque mesmo assumindo finalidades realizáveis, não se pode assumir a priori que sua realização é diretamente compatível com uma sociedade sustentável.

Vale recordar que meu objetivo neste trabalho não é simplesmente dirigir uma crítica a certos aspectos pontuais das ideias ecossocialistas (para as quais, em geral, convirjo). O objetivo é, por meio dessas incursões críticas, demonstrar as exigências - algumas delas, bastante novas, como veremos nas duas seções seguintes - que a crise climática impõe à humanidade e ao campo marxista. Pelo que foi discutido nessa seção, há motivos para concluir que essas lutas precisam ser ativamente transformadas para que enfim manifestem sua potência emancipatória e ecológica e se tornem meios adequados para a sobrevivência da espécie e a preservação de seu pressuposto mais básico, o meio natural.

Para além da adesão acrítica ao conjunto das lutas de inspiração trabalhista, o que explicaria a notável relutância em questionar abertamente certas pautas orientadas por princípios produtivistas e desenvolvimentistas, mesmo entre aqueles que reconhecem o caráter antiecológico da sociedade capitalista e, ao mesmo tempo, assumem como finalidade última do seu engajamento em lutas sociais a construção de uma sociedade pós-capitalista sustentável? Basicamente, duas ideias muito difundidas: primeiramente, a de que o acúmulo de reformas e vitórias (ecológicas) sobre o capital representam avanços que podem, eventualmente, desdobrar-se em efetiva transformação qualitativa; em segundo lugar, complementar ou alternativa à primeira, a de que as pequenas vitórias no varejo nos ganham tempo precioso e mantêm a base mobilizada até que se reúnam as condições necessárias para os verdadeiros processos de ruptura e mudança. Tratamos desses dois pontos nas duas seções seguintes. 


\section{Meios inadequados: a noção de acúmulo progressivo de avanços}

[O] que tem a potência para ser pode ser e também pode não ser (Aristóteles, 2002, p. 423).

Em abstrato, a noção de que um acúmulo progressivo de pequenas alterações pode eventualmente desdobrar-se em um salto - i.e. em um processo de ruptura e transformação qualitativa substancial - é perfeitamente compatível com a perspectiva dialética. Concretamente, contudo, nosso campo de preocupações apresenta especificidades que exigem trazer ao primeiro plano ao menos duas objeções. A primeira, em relação à noção de avanço e a segunda em relação à própria possibilidade de um salto.

Quanto às especificidades, podemos afirmar que, no caso das mudanças climáticas, a categoria da totalidade possui, além da centralidade ontológica ${ }^{8}$, uma centralidade prática. Ao contrário de diversos impactos ambientais locais que podem ser minorados ou até mesmo superados por medidas pontuais e parciais (como uma nova legislação ou rechaço popular sobre uma determinada atividade econômica poluente, por exemplo), o fenômeno das mudanças climáticas é irremediavelmente global. Sua causa principal é a elevação da temperatura média do planeta, provocada especialmente pela elevação da concentração de gases de efeito estufa (GEE) na atmosfera, impulsionada pelas emissões antropogênicas desses gases (IPCC, 2014).

Essa estrutura causal básica nos informa o seguinte: a atividade humana afeta os sistemas climáticos do planeta porque suas emissões periódicas alteram a química atmosférica. Como? Anualmente, emitimos aproximadamente $45 \mathrm{GtCO}_{2 \mathrm{e}}$ de GEE. Desse volume, cerca de $4,4 \mathrm{GtCO}_{2 \mathrm{e}}$ são absorvidos por sistemas terrestres e oceânicos ${ }^{9}$. O restante é absorvido pela atmosfera. A cada 8 $\mathrm{GtCO}_{2 \mathrm{e}}$ absorvidos pela atmosfera, a concentração de GEE se eleva em 1 ppm (Lovelock, 2009). Qualquer nível total de emissões que exceda a capacidade global de absorção não-atmosférica atua, portanto, no sentido de aumentar a concentração atmosférica de GEE.

Isso nos permite questionar, já neste primeiro momento, a ideia de avanço incremental de reformas em dois níveis. Não há avanço quando um país (ou mesmo um conjunto de países) realiza uma redução de seu nível de emissões se, no conjunto das nações do globo, as emissões totais aumentam. A influência antropogênica nas mudanças climáticas se amplifica; e em velocidade crescente. Da mesma forma, mesmo assumindo que um esforço global obtenha reduções sustentadas do nível total de emissões, se esse nível permanecer acima da absorção não-atmosférica, também cresce a influência antropogênica no fenômeno, embora em menor velocidade.

Este segundo caso oferece, em um relance, os pilares mais básicos do desafio diante da humanidade. Não por acaso, proliferam há alguns anos, mesmo nos documentos mais pretensamente sóbrios, clamores pelo desenvolvimento e emprego de tecnologias de extração de carbono na atmosfera $^{10}$.

(8) Para uma demonstração rigorosa dessa centralidade no pensamento marxiano, cf. Lukács (2012, cap. IV).

(9) Esse valor é uma média anual estimada para o período de 1750 a 2011 (IPCC, 2014). Mas esse número pode variar. Desflorestamento e acidificação dos oceanos, por exemplo, tendem a deprimir a capacidade de absorção não-atmosférica de CO2 e outros gases (Lovelock, 2009; Steffen et al., 2018; USGCRP, 2018).

(10) Cf. IPCC $(2014 ; 2018)$. 
Mesmo assim, uma perspectiva radicalmente otimista poderia ainda tentar sustentar que, até nestes cenários em que a influência humana não é contida, os resultados obtidos pelos esforços empreendidos nos deixam em uma situação melhor do que no cenário alternativo, de inexistência desses esforços. Por isso, preciso explorar um terceiro nível em que a ideia de avanço incremental pode ser questionada.

Segundo Löwy (2005, p. 20), não ter

ilusões sobre "ecologizar" o capitalismo não significa que não se pode entrar na batalha por reformas imediatas. Por exemplo, certos tipos de impostos ecológicos poderiam ser úteis, desde que fossem baseados numa lógica social igualitária (os poluidores pagam, e não o público) e que se eliminasse o mito do cálculo econômico do "preço de mercado" dos danos ecológicos, que são incomensuráveis por qualquer ponto de vista monetário.

É muito difícil atender ao desejo de Löwy e associar qualquer lógica que não a de mercado a essa formulação. Nesta passagem, o autor adere integralmente (a não ser por sua rejeição nominal da perspectiva monetária) a um princípio muito caro à Economia Ambiental ${ }^{11}$ : a internalização das externalidades. O raciocínio aí implicado sustenta que a degradação ambiental é provocada por uma atividade produtiva excessiva, que ocorre porque o cálculo econômico das firmas não leva em consideração danos materiais/ambientais que não se convertem diretamente em custos operacionais. Os impostos ecológicos cumpririam, nesse registro, a função de forçar os produtores a inserirem os custos ambientais em seu cálculo econômico. Isso, supõe-se, os levaria a um nível de atividade mais baixo, com menor nível associado de impacto ambiental. Daí derivaria seu caráter útil, tanto para Economia Ambiental quanto, aparentemente, para Löwy.

Vemos uma versão diferente da mesma ideia quando Williams $(2010$, p. 147, 150) afirma: "Mudanças estruturais mais amplas devem significar reduzir o poder das corporações pressionando os governos a regular suas operações. [...] São as corporações que devem fazer sacrifícios, não nós". Assim, Williams e Löwy (e tantos outros) se restringem à análise das manifestações particulares do capital. Do ponto de vista do capital global, não há sacrifício (voluntário ou imposto).

Restrições à sua operação em um tipo determinado de atividade desdobram-se em economia de capital, pois a magnitude exigida para operar ali é reduzida pela diminuição da escala de operação. Dizendo de outra forma, as restrições liberam capital, que não pode, dada sua própria natureza, acomodar-se na imobilidade. Aquele capital liberado em um ponto do sistema precisa encontrar outro espaço de atuação para realizar o seu movimento expansivo. Do ponto de vista da totalidade, há apenas a redistribuição do capital em sua dinâmica expansiva. Do ponto de vista da materialidade, não há absolutamente nada que garanta que a redução de impacto efetivada em âmbito local se traduza em redução de impacto geral. Ao contrário, como veremos na seção seguinte, é possível demonstrar que a tendência é que ocorra exatamente o oposto.

Isso não quer dizer que as configurações materiais do capital não importam, que são indiferentes/homogêneas em relação ao meio ambiente. Quer dizer apenas que há uma dinâmica estrutural que ora neutraliza os avanços, ora converte a vitória em um ponto do sistema em derrota no plano geral. Não sustento que esse mecanismo de neutralização é um determinante geral, a-

(11) Linha de pensamento que é a manifestação teórica das "preocupações" do capital com o meio ambiente. 
histórico, da vida humana em sociedade. Sua operação devém do caráter de valor da riqueza social, de seu movimento como capital e da natureza expansiva que o capital necessariamente imprime nela, inclusive do ponto de vista material.

Mesmo abstraindo momentaneamente essas objeções, ainda é preciso fazer um contraponto à noção de mudanças substanciais produzidas por um acúmulo de mudanças incrementais. Conforme Engels (1979, p. 35) nos mostra, a lei da transformação da quantidade em qualidade é um princípio do funcionamento da própria realidade, e não apenas uma fórmula logicista da dialética. No entanto, parece indevido o salto à conclusão de que esse princípio da transformação da quantidade em qualidade opera sempre de maneira convergente às nossas finalidades e via quaisquer meios que mobilizemos para sua realização. Tal salto geralmente não é enunciado explicitamente, mas a literatura ecossocialista ocasionalmente apresenta esse tipo de raciocínio, como vemos no trecho extraído de Löwy (2005, p. 21), abaixo:

A luta pelas reformas ecossociais pode ser o veículo para a mudança dinâmica, uma "transição" entre as exigências mínimas e o programa máximo, desde que se rejeite a pressão e os argumentos dos interesses dominantes por "competitividade" e "modernização" em nome das "regras do mercado".

Aqui, o autor simplesmente supõe que um conjunto mínimo de meios (a luta por reformas ecológicas e a rejeição abstrata de valores tipicamente capitalistas, como competitividade, modernização etc.) garante que um programa de mínima ambição (sem que saibamos em nenhum momento qual seria um conjunto suficiente dessas demandas mínimas) converte-se num resultado de máxima realização (uma sociedade ecologicamente sustentável, suponho).

No capítulo sobre a cooperação, em $O$ capital, Marx nos fornece boas indicações para tratar essas mediações com mais rigor. A maior parte do capítulo é dedicada a demonstrar como a força produtiva do trabalho é majorada quando se considera a cooperação (em oposição à mesma quantidade de trabalhos individuais realizados isoladamente). Mas para o nosso tema, o crucial é outro tipo de pista: aquela que permite concluir que certos processos e certas realizações são simplesmente inviáveis na ausência dessa articulação cooperativa dos esforços e em uma escala e escopo mínimos. Em outros termos, mais concretos, se, por um lado, é concebível que a realização de certas finalidades seja compatível com esforços pulverizados, desarticulados, não-cooperativos e incrementais, também é fácil perceber, por outro lado, que haverá objetivos para os quais esse tipo de mobilização do agir humano será irremediavelmente insuficiente.

Quando Marx (2013, p. 409) afirma, por exemplo, que o "efeito da cooperação simples se apresenta de modo colossal nas obras gigantescas dos antigos asiáticos, egípcios, etruscos etc.", temos a ilustração não apenas de uma força produtiva superior existente no trabalho combinado, mas também de um caso evidente em que a realização é inviável na ausência da combinação simultânea e coordenada dos esforços. Pelas características da finalidade (mover blocos de pedra colossais, por exemplo), não existe nenhuma combinação de esforços via acúmulo progressivo da contribuição isolada de cada trabalhador que se constitua como meio capaz de realizar o objetivo. A coordenação dos esforços, sua escala e sua aplicação em fluxo determinado e adequadamente orientado aparecem como precondições do feito. 
Em outra passagem, encontramos uma formulação mais geral para a mesma ideia, que permite uma aproximação maior para a nossa questão, a de como o campo ecossocialista deve se mobilizar frente às mudanças climáticas:

Todo trabalho imediatamente social ou coletivo em grande escala requer, em maior ou menor medida, uma direção que estabeleça a harmonia entre as atividades individuais e cumpra as funções gerais que resultam do movimento do corpo produtivo total em contraste com o movimento de seus órgãos autônomos. Um violinista isolado dirige a si mesmo, mas uma orquestra requer um regente (Marx, 2013, p. 406; ênfase adicionada).

Por falar em grande escala, as tarefas impostas pelas mudanças climáticas para a sobrevivência humana (e para a adaptação a condições ambientais sem precedentes para a espécie) são de tamanha magnitude e complexidade que a comunidade científica - a princípio sem nenhuma inclinação substantiva a ideias e práticas subversivas - sequer cogita a possibilidade de que esforços pulverizados e desarticulados sejam adequados, ou mesmo aceitáveis. Em 2014, o $\operatorname{IPCC}(2014$, p. 26) já alertava, de maneira ainda relativamente reticente, que muitas "opções de adaptação e mitigação podem ajudar a lidar com as mudanças climáticas, mas nenhuma opção é suficiente por si só. A implementação efetiva depende de políticas e cooperação em todas as escalas e pode ser aprimorada por meio de respostas integradas que vinculam adaptação e mitigação a outros objetivos sociais". Apenas quatro anos depois, o teor da recomendação é consideravelmente mais incisivo:

Trajetórias que limitam o aquecimento global a $1,5^{\circ} \mathrm{C}$, sem overshoot ou com overshoot limitado, exigiriam transições rápidas e de longo alcance em energia, campo, cidades, infraestrutura (incluindo transporte e edifícios) e sistemas industriais. Essas transições sistêmicas não têm precedentes em termos de escala [...] e implicam reduções profundas de emissões em todos os setores, um amplo portfólio de opções de mitigação e um significativo aumento de investimentos nessas opções. [...] As taxas de mudanças sistêmicas associadas à limitação do aquecimento global a $1,5^{\circ} \mathrm{C}$, sem overshoot ou com overshoot limitado, ocorreram no passado dentro de setores, tecnologias e contextos espaciais específicos, mas não há nenhum precedente histórico documentado para sua escala (IPCC, 2018, p. 21; ênfase adicionada).

Seria injusto acusar os autores ecossocialistas de não reconhecerem a necessidade de transformações estruturais. Todos o fazem, por força de seu entendimento do caráter insustentável da sociedade capitalista. Todavia, o tipo de posicionamento que criticamos nesta seção encontra ainda espaço em nosso campo porque falta uma noção clara da possibilidade de a atividade humana já ter desestabilizado de maneira irreversível o sistema climático que propiciou as condições ecológicas sobre as quais nossa espécie surgiu e floresceu, e de já estarmos em meio a mudanças climáticas abruptas que desafiarão nossa capacidade de adaptação no curto prazo. Sem um entendimento rigoroso dessas possibilidades, vemos proliferar menções vazias a um hipotético "médio ou longo prazo", em que a necessidade de transformações substantivas se imporia ferreamente. Isso, por sua vez, permite o predomínio, no curto prazo, de uma espécie de finalidade subsidiária que almeja tão somente "ganhar tempo". 


\section{Meios inexistentes: sobre a possibilidade de ganhar tempo}

[O] que não tem potência de ser não pode existir em parte alguma [...] (Aristóteles, 2002, p. 423).

Quando aplicada ao fenômeno das mudanças climáticas, a ideia de ganhar tempo visa obter qualquer avanço possível capaz de desacelerar a influência desestabilizadora da atividade humana sobre o sistema climático. Nessa formulação, encontramos ao menos dois pressupostos implícitos: o da possibilidade de avanços (i.e., de processos suficientes para ao menos desacelerar nossos impactos) e o da disponibilidade de tempo (i.e., da possibilidade de ainda evitar uma desestabilização irreversível das condições climáticas do planeta). Isso transparece claramente em duas passagens de Williams (2010):

No curto prazo, movimentos socioecológicos de base devem construir lutas independentes por reformas que retardarão a degradação diária do meio ambiente causada pela atual estrutura econômica e social (p. 193; ênfase adicionada).

Os ativistas socioecológicos precisam lutar por um programa governamental regulatório focado em ganhos de eficiência [...], o que reduziria consideravelmente o consumo de energia. [...] No entanto, como o objetivo subjacente importa, os ganhos em tecnologia e eficiência, por si só, não são uma solução de longo prazo para a crise ambiental (p. 199-200; ênfase adicionada).

Mais uma vez, a crença abstrata em uma redução (ou desaceleração) de impactos ou de degradação se apoia no fato de que, em âmbito local, é frequentemente possível obter esses resultados. Como já discutido na seção anterior, no entanto, a transposição desses eventuais sucessos parciais para o plano da totalidade é indevida enquanto predominar sobre o metabolismo entre sociedade e natureza a dinâmica própria do capital. O trecho extraído de Williams dá oportunidade para avançar nessa crítica.

Ali, declara-se explicitamente a expectativa de que reformas orientadas para os ganhos de eficiência gerariam, ao menos no curto prazo, economia efetiva de energia ${ }^{12}$. Não por acaso, recomendações como essa encontram-se presentes nos mais importantes documentos sobre mudanças climáticas publicados na última década ${ }^{13}$. Paralelamente, políticas inspiradas em concepções como essa foram implementadas por inúmeros países e governos e comunidades locais, muitas vezes com expressivo sucesso em termos de elevação dos níveis de eficiência energética (Sá Barreto, 2018). Esses resultados, contudo, não vieram acompanhados da diminuição esperada no consumo total de energia. Ao contrário, o que se observou foi o aumento persistente desse consumo.

Em trabalho anterior, procurei demonstrar como a dinâmica de elevação das forças produtivas própria da sociedade capitalista necessariamente se traduz, entre tantas outras coisas, em expansão do nível total de consumo material e energético da atividade humana (Sá Barreto, 2014a). Neste ponto de nossa discussão, podemos reproduzir parte dos raciocínios ali presentes, reformulando-os de modo a enfatizar outro aspecto do mesmo problema, redirecionado o foco mais estrito sobre as forças

(12) Consumindo menos energia, emite-se menos GEE, para qualquer nível dado de intensidade em emissões.

(13) Cf., por exemplo, IPCC (2007; 2014; 2018); Stern (2007); USGCRP (2018) e Guterres (2018). 
produtivas em favor de uma mirada mais abrangente, sobre qualquer impulsionador potencial de economia de recursos.

Interessa, além disso, direcionar a discussão para o caso em que o ganho de eficiência energética é impulsionado por imposições externas ao funcionamento mais ou menos espontâneo do mercado e ao comportamento mais ou menos voluntário dos capitais particulares. Há um motivo muito claro para essa escolha. O conjunto da literatura ecossocialista não alimenta qualquer ilusão de que o capital seja capaz de se autorregular em qualquer direção compatível com a sustentabilidade ecológica. $\mathrm{O}$ mesmo não pode ser dito a respeito de um capitalismo regulado pelo Estado, sob a pressão de reivindicações populares. Em geral se espera, como já afirmado no início da seção, que a regulação e as reformas ecologicamente orientadas sejam capazes de operar pequenos avanços que, embora insuficientes, permitem ganhar tempo.

Mas o que seria avanço, neste registro pouco ambicioso? Se o assunto é mudança climática, quase sempre se assume como avanço a contenção da expansão das emissões antropogênicas de GEE. Supõe-se que, uma vez realizado o potencial poupador criado pelo aumento da eficiência energética, consome-se menos energia e, portanto, emite-se menos GEE. O problema reside justamente na realização deste potencial.

É perfeitamente possível que uma fábrica, um domicílio, um setor produtivo inteiro, uma cidade inteira ou até mesmo um país inteiro traduzam maiores níveis de eficiência em menor consumo de energia. Basta que a economia relativa proporcionada pela maior eficiência não seja compensada/neutralizada por uma expansão das atividades consumidoras de energia. Perceba que este já seria um feito considerável. Completando este feito, podemos também afirmar que, naqueles casos, é perfeitamente possível que se converta o menor consumo de energia em menor nível de emissões. Bastaria que a intensidade em emissões por unidade de energia consumida não aumentasse (ou ao menos não aumentasse o suficiente para neutralizar os ganhos do consumo menor).

Por mais significativos que sejam tais feitos, do ponto de vista da mudança climática, eles só representam avanço de fato se as emissões totais forem reduzidas. E não apenas reduzidas em qualquer magnitude, mas em magnitude suficiente para trazer o nível de emissões abaixo da capacidade de absorção do conjunto dos sistemas terrestres e oceânicos. É reflexo direto disso a ênfase crescente do IPCC $(2014 ; 2018)$ em emissões líquidas nulas ou negativas ${ }^{14}$, o que exigiria, além da redução de emissões, o emprego massivo de tecnologias de extração de carbono da atmosfera. Tratarei disso mais detidamente quando chegar à discussão sobre a possibilidade de ganharmos tempo. Por ora, é preciso responder: o que impede que a realização do potencial poupador de energia (e emissões) em âmbitos restritos transborde para o plano da totalidade?

Como já discutido na seção anterior, a própria natureza do capital. A energia poupada não é apenas energia, uma coisa existente exclusivamente na realidade física. É também capital e, portanto, capital poupado. E como capital, não se compraz com a inatividade. Isto é, não pode se realizar como economia material de fato porque sua forma social a impele ao movimento expansivo. Essa vocação nem sempre se manifesta no plano de operação do capital particular porque uma série de restrições podem desviá-la para outros espaços. Por exemplo, um determinado setor que experimenta um salto

(14) Para as definições, cf. IPCC (2018, p. 554-555). 
tecnológico com grandes ganhos de eficiência energética pode eventualmente não ter condições de transformar essa reconfiguração da sua estrutura de custos em expansão da produção. Talvez o mercado esteja saturado, talvez regulações estatais limitem em termos absolutos aquela atividade, talvez não haja um fluxo suficiente disponível de matérias-primas etc. Em qualquer um desses casos, a magnitude do capital necessária para operar em qualquer nível dado de atividade será menor. Assumindo essa conjugação de maior eficiência e restrições externas, um menor volume de energia será consumido. Mas, além disso, uma massa de capital que antes se convertia (como capital constante) no consumo daquela energia é liberada. Como esse capital não encontra as condições para operar em seu setor de origem, precisa encontrar outra atividade lucrativa viável para manter seu movimento expansivo. E quando a encontra, assume necessariamente formas materiais consumidoras de energia.

A mediação entre ganho de eficiência energética e avanço real exigiria que a matéria-energia poupada permanecesse imóvel, não-consumida em nenhum outro ponto do metabolismo entre sociedade e natureza. No capitalismo, contudo, ela simplesmente encontra outro espaço para se mover. E sustentar que esse capital pode ser direcionado para os circuitos de valorização fictícia (uma tendência clara no tempo presente) é apenas mais um momento da falta de rigor teórico que ora abstrai totalmente da dimensão social das categorias (esquecendo que a energia poupada é também capital poupado), ora abstrai de sua dimensão material (esquecendo que o capital fictício apresenta vínculos incontornáveis com a materialidade $)^{15}$.

Da mesma maneira, é absolutamente incorreto um outro tipo de fuga conceitual abstrata ${ }^{16}$, que deposita todas as expectativas de poupança de recursos na generalização da moderação no consumo doméstico. É incorreto por dois motivos. Em primeiro lugar, a moderação do consumo nunca pode se generalizar a ponto de representar contração absoluta do consumo. Pode-se demonstrar que o capital materialmente ativo produz em escala, escopo e velocidade crescentes e, por isso, exige consumo (no plano da totalidade) em escala, escopo e velocidade crescentes (Sá Barreto, 2014b). Em segundo lugar, porque mesmo para um domicílio particular, a poupança nunca é apenas material. É também poupança de riqueza em sua forma social. E mesmo que essa riqueza não tenha, de maneira imediata, o caráter de capital, também é possível demonstrar que sua conservação como tesouro imóvel fora da circulação tende a deteriorá-la e que, então, ela tende a ser lançada nos circuitos da circulação como capital (Medeiros; Leite, 2016) - ou mesmo diretamente em outras modalidades de consumo improdutivo. Em ambos os casos, desdobram-se os mesmos resultados de neutralização das economias materiais.

Dessa forma, percebe-se que a impossibilidade de economia material absoluta - originada na impossibilidade de imobilidade do capital no âmbito da totalidade - que se revela inicialmente na

(15) A categoria capital fictício indica um título negociável de apropriação sobre mais-valor futuro. O preço desse título, por sua vez, é em parte determinado pelo fluxo de renda já realizado por um capital materialmente atuante. Além disso, o "valor de mercado desses papéis é, em parte, especulativo, pois não depende somente dos ganhos reais, mas também dos ganhos esperados, calculados por antecipação" (Marx, 2017, p. 525). No entanto, por mais que sua dinâmica se autonomize relativamente da ulterior produção desse maisvalor, o vínculo com a produção real não se rompe em definitivo, como indica Sabadini (2013, p. 602; ênfase adicionada): "o desenvolvimento do capital fictício - caracterizado por diversos instrumentos financeiros como as ações, títulos públicos... - dissimula ainda mais as conexões com o processo real de valorização do capital, consolidando a imagem de que ele se valoriza por si mesmo, nas transações de compra e venda especulativas".

(16) Muito mais comum nas concepções conservadoras do que nas ecossocialistas. 
discussão sobre eficiência energética é extensível a todas as demais maneiras pelas quais se pode impor economia material no âmbito restrito dos capitais particulares. Não se trata, para que não reste dúvidas, de uma afirmação de impossibilidade trans-histórica, mas de uma impossibilidade circunscrita ao tipo de metabolismo social produzido pelo capital.

Temos então que esse metabolismo é incompatível não apenas com uma ideia genérica de sustentabilidade ecológica de longo prazo, mas também com qualquer noção de curto prazo e pouco ambiciosa de alívio ou desaceleração de nosso impacto desestabilizador sobre o clima do planeta. Se admitimos essa conclusão, restam duas perguntas: quanto tempo ainda temos até que essa dinâmica ecocida destrua as condições materiais de uma sociedade emancipada e sustentável?; quanto tempo ainda temos até que ela destrua quaisquer condições de suporte à vida na Terra? Desnecessário dizer, não é meu objetivo oferecer uma previsão quantitativa. Sustento, porém, que é possível inferir uma imagem de futuro bastante definida a partir das manifestações da comunidade científica, dos mecanismos naturais sobre os quais temos razoável compreensão e sobre as estatísticas climáticas fornecidas por instituições confiáveis.

Dois termos muito utilizados no debate climático são úteis para nos aproximarmos das respostas: mitigação e adaptação. $\mathrm{O}$ conceito de mitigação apoia-se na possibilidade de que o redirecionamento de nossa influência sobre o clima seria capaz de evitar os impactos de maior risco das mudanças climáticas. O de adaptação, por sua vez, apoia-se no reconhecimento de que alguns (e em número sempre crescente, quanto mais se adia uma mobilização global substantiva) impactos já são inevitáveis e que precisamos estar aptos a navegar nesse planeta em transformação. Tomando os relatórios do IPCC como principal referência, percebemos um claro deslocamento de foco entre os conceitos. Até a AR4, a ênfase principal recaia sobre mitigação (IPCC, 2007). Na AR5, a ênfase passa a uma mitigação fortemente dependente de tecnologias de geoengenharia (IPCC, 2014). Apenas quatro anos depois, em sua Special Report (SR15) de 2018, a ênfase desloca-se abruptamente para a adaptação fortemente dependente de geoengenharia e com elevados níveis de incerteza. Não é difícil ilustrar resumidamente as lições da SR15.

Em diversos momentos do extenso relatório é afirmado que para limitarmos o aumento da temperatura média a $1,5^{\circ} \mathrm{C}$ (assumido como meta desejável para a ação global), precisaríamos de dramáticas reduções das emissões: redução de $45 \%$ até $2030^{17}$, em relação ao nível de 2010 e atingir zero emissões antropogênicas líquidas [net zero emissions] até 2050 e, possivelmente, emissão líquida negativa [net negative emissions]. Emissão antropogênica líquida é a diferença entre tudo que emitimos e tudo que retiramos (por ação humana direta) da atmosfera, logo irremediavelmente dependente de técnicas de remoção de $\mathrm{CO}_{2}$ (e outros gases) da atmosfera.

O leitor otimista, então, rapidamente reanima toda a sua fé na dinâmica tecnológica da sociedade capitalista e se sente confortável com a meta de $1,5^{\circ} \mathrm{C}$. Mas o que está subjacente a esse enunciado sintético que diz que precisamos limitar o aumento da temperatura a $1,5^{\circ} \mathrm{C}$ mobilizando todo o potencial de nosso gênio inovativo?

(17) Não custa lembrar ao leitor que todos os esforços até hoje empreendidos sequer foram capazes de conter o persistente crescimento do nível de emissões. 
Primeiro, a segurança da meta é questionável. O próprio IPCC admite que existe uma pequena possibilidade de os processos de desestabilização climática tornarem-se irreversíveis já no patamar de $1^{\circ} \mathrm{C}$. Assumindo, no entanto, que $1,5^{\circ} \mathrm{C}$ seja um nível seguro, atingir emissões negativas exigiria o emprego de tecnologias de remoção de $\mathrm{CO}_{2}$ (incluídas aí tecnologias experimentais, especulativas ou simplesmente ainda inexistentes) em escala, escopo e velocidade sem precedentes. Ainda, se aceitarmos a segurança da meta e supusermos o perfeito sucesso dos meios tecnológicos recomendados, o IPCC ainda nos informa que a probabilidade de o aquecimento ser efetivamente mantido abaixo de $1,5^{\circ} \mathrm{C}$ varia de modestos $50 \%$ a pouco animadores $66 \%$ (IPCC, 2018, p. 113-114). Para completar, descobrimos ao final do capítulo 2 que todo esse malabarismo estimativo está sustentado sobre uma lacuna de conhecimento. Na seção knowledge gap, é anunciado que "A quantificação das maneiras como o ciclo do carbono responde a emissões negativas é uma importante lacuna de conhecimento, considerando trajetórias agudas de mitigação" (IPCC, 2018, p. 157). Em outros termos, simplesmente não se sabe ao certo se o ciclo do carbono reagirá da maneira desejada à retirada massiva de carbono da atmosfera; o que recomendaria prudência ainda maior quanto ao carbono que emitimos.

Temos aqui dois resultados decisivos: a abrangência e intensidade da mobilização global recomendada pelo IPCC já é muitas vezes mais ambiciosa, disruptiva e curto-prazista do que a que encontramos na literatura ecossocialista. Mesmo ela, contudo, não parece alcançar plenamente a dramaticidade concreta de nossa situação. Além das ponderações apresentadas no parágrafo anterior, há pelo menos três indícios claros de que o cenário é mais grave do que a leitura predominante do IPCC. Primeiro, existe um reconhecido e amplamente relatado viés de moderação na comunicação científica das sínteses de descobertas e projeções ${ }^{18}$. A esse aspecto me referia quando, ainda na introdução, fiz menção a publicações conservadoras. Segundo, o relatório do IPCC incorpora apenas marginalmente a consideração a respeito de mecanismos de feedback positivo sobre a mudança climática $^{19}$. Por fim, se compararmos o conceito-chave de "pré-industrial" com o que é realmente computado pelo IPCC e outras publicações, surge uma dissonância importante.

Sabemos que a Revolução Industrial é um fenômeno histórico de início em meados do século XVIII. Por isso, quando as primeiras menções à meta de $2^{\circ} \mathrm{C}$ começaram a aparecer, o ano-base adotado era 1750. Ao mesmo tempo, as efetivas medições publicadas da elevação da temperatura média do planeta parecem mudar muito lentamente, o que não daria causa para alarme. No entanto, raramente o leitor leigo percebe que a base de referência vem se deslocando. Na SR15, a base é uma média de temperatura para o período de 1850 a 1900 (sem que seja abandonado o termo "préindustrial"). Por essa base, o aquecimento experimentado foi de aproximadamente $0,87^{\circ} \mathrm{C}$ (IPCC, 2018 , p. 4). Para a NASA (2019) já rompemos a barreira de $0,9^{\circ} \mathrm{C}$ de aumento, mas a base considerada é uma média entre os anos de 1951 a 1980 (!). Se formos rigorosos com a base efetivamente préindustrial (ano-base: 1770), o que verificamos é um aumento estimado de $1,5^{\circ} \mathrm{C}$ (Berkeley Earth, 2019), exatamente o nível que deveria ser supostamente evitado com ações a se prolongarem muito além da metade deste século.

(18) Cf. Hansen (2007); Spratt e Dunlop (2018); Rahmstorf et al. (2007) e Lovelock (2009).

(19) "Os modelos climáticos de complexidade reduzida empregados nesta avaliação não levam em conta os feedbacks de permafrost ou de sistemas não-CO2” (IPCC, 2018, p. 104). 
Diante de todas essas informações, não é mais possível, por quaisquer noções distorcidas de médio e longo prazo, projetar para o futuro a via disruptiva, com todas as transformações que sabemos necessárias. Não só é fundamental defender sua urgência imediata, como é bem possível que mesmo elas não sejam mais suficientes para sustentar uma sociedade emancipada ou para impedir, na pior hipótese, que o planeta se torne inabitável para nossa espécie.

\section{Navegando o perigo da desmobilização}

Conforme adiantado ainda na introdução, o prognóstico delineado é gravemente sombrio. Se o raciocínio elaborado até aqui estiver correto, descobrimos que há múltiplas e sólidas evidências de que já está fora de nosso alcance qualquer possibilidade de condução ${ }^{20}$ consciente da dinâmica climática do planeta. Sintoma claro disso é a convocação do IPCC ao uso da força bruta da geoengenharia (em parte ainda puramente especulativa) apenas para evitar os impactos de maior risco existencial e com uma probabilidade estimada de sucesso muito pouco animadora. Depreende-se disso que as condições materiais e ecológicas para uma futura sociedade emancipada e sustentável desaparecem em velocidade febril, se é que já não foram completamente destruídas. A lógica aqui é muito simples: se as condições de sobrevivência da espécie humana se encontram sob risco de iminente destruição, as condições de pleno florescimento e segurança material da sociedade só podem estar ameaçadas de maneira ainda mais aguda. Descobrimos, por fim, que o amplo e consagrado conjunto de formas de atuação da classe trabalhadora é, na melhor das hipóteses, profundamente impotente diante desses desafios.

É perfeitamente compreensível que a reação imediata a esse quadro seja de rejeição. Também é legítimo que se aponte seu potencial fortemente desmobilizador. Se o futuro é necessariamente trágico e tudo aquilo que é feito é inútil, não haveria motivo para se engajar nas lutas contra o avanço destrutivo do capital. Sem dúvida, essa é uma reação muito frequente; mas trata-se de um non sequitur. Diante da tragédia iminente e da impotência das lutas em curso, não há motivos para reproduzir as lutas em curso. Mas isso não se aplica a qualquer tipo de luta. Entre as tragédias possíveis, um cenário de colapso da civilização é claramente preferível à extinção. Voltar à idade da pedra está longe de qualquer imagem que poderíamos formar de um comunismo ecológico, mas sermos arrastados na sexta extinção em massa, já em curso, está certamente muito mais distante.

Reconheço que não é nem um pouco inspirador se defrontar com esse conjunto de futuros possíveis. Porém, a teoria e as evidências disponíveis não permitem visualizarmos futuros idílicos. Nesse sentido, podemos recordar, por exemplo, o que diz Lukács (2013, p. 138-139):

até no trabalho mais simples aparecem certos pontos nodais das decisões nos quais o direcionamento para um lado ao invés de para outro pode acarretar um "período de consequências", no qual o espaço de ação da decisão se torna extremamente limitado e, sob certas circunstâncias, praticamente nulo. Até nos jogos, por exemplo no xadrez, pode suceder uma situação, ocasionada em parte pelas próprias jogadas etc., em que existe apenas uma possibilidade forçosa de jogada.

(20) O termo "condução" é uma tradução livre de steer, que evita propositalmente a noção de controle sobre (ou reversão das) transformações climáticas, já há muito abandonada no debate sobre a questão (exceto por economistas e cientistas sociais ainda resistentes em se aprofundar em literatura estranha aos seus nichos acadêmicos). 
Se tudo leva a crer que entramos em um "período de consequências" climáticas, a tarefa prioritária é conhecer, tanto quanto possível, as direções prováveis dessas consequências e, portanto, as finalidades que continuam sendo realizáveis. Em seguida, delimitar rigorosamente o "espaço de ação das alternativas concretas", contemplando de maneira franca quais dessas ações podem de fato se constituir como meios adequados para a realização da finalidade. A postura mais estéril, me parece, consiste em defender e proteger a priori um certo tipo determinado de atuação, por mais tradicional, consagrado ou bem-sucedido que tenha sido historicamente.

Muitas vezes, essa defesa a priori vem disfarçada de argumento baseado em Marx. Burkett (1999), por exemplo, recorre a Marx e Engels não apenas para sustentar que todas as lutas da classe trabalhadora convergem para a finalidade ecossocialista (como vimos na primeira seção), mas também para alegar que os reais ganhos dessas lutas não são seus resultados imediatos, mas a própria construção de uma unidade de classe. Essa unidade, continua ele recorrendo textualmente a Marx, criaria um tipo de postura indiferente (ou mesmo desdenhosa) da classe trabalhadora diante da destruição econômica que suas reivindicações imporiam sobre o capital. No trecho usado por Burkett, Marx afirma:

Se nas associações realmente fosse apenas uma questão do que parece ser, ou seja, a fixação de salários, se a relação entre trabalho e capital fosse eterna, essas combinações seriam destruídas pela necessidade das coisas. Mas elas são o meio de unir a classe trabalhadora, de preparar a derrubada de toda a velha sociedade e suas contradições de classe. E, desse ponto de vista, os trabalhadores têm razão em rir dos inteligentes mestres burgueses que os confrontam com aquilo que essa guerra civil os está custando em termos sacrifícios humanos e financeiros. Aquele que quiser vencer o adversário não discutirá com ele os custos da guerra (Marx; Engels, 1976, p. 435).

Creio que podemos falar com certa segurança que esse tipo de expectativa dificilmente encontra qualquer aderência com a história das lutas trabalhistas desde Marx. Seria um desafio encontrar qualquer exemplo concreto em que os trabalhadores em luta tenham rido desdenhosamente quando os sacrifícios financeiros impostos por eles ao capital tenham ameaçado de maneira não passageira seus postos de trabalho. Isso equivaleria a rir da destruição das condições de emprego e, como desdobramento, da destruição dos meios materiais de vida do trabalhador em uma sociedade capitalista. Quão rigoroso é esperar que, mergulhada na batalha do cotidiano, se desenvolva espontaneamente na classe trabalhadora - sem uma referência direta, explícita e a priori à finalidade emancipatória (e às rupturas por ela exigidas) - a disposição para rir deste cenário?

Mesmo que pudéssemos admitir a validade dessas intuições no âmbito da tensão entre o mundo capitalista e uma outra forma de organização socioeconômica possível, a transposição dessa validade para o âmbito da tensão entre sociedades humanas e as condições materiais da vida humana não é automática. Ela (a transposição) requer investigação. E toda nossa investigação leva a crer que não resta dúvida da inadequação desse tipo de fórmula se se espera que as lutas sociais tenham algum sucesso em garantir condições mínimas para a existência continuada de nossa espécie no planeta.

A esperança na fermentação de uma unidade e direção mais ou menos automática contrasta enfaticamente com a reflexão de um dos mestres do pensamento político. Conforme vemos em Gramsci, um processo paciente ${ }^{21}$ de consolidação e formação de uma força coesa e capaz, a ser

(21) A medida da paciência é limitada, claro, pelo tempo disponível. 
liberada em momento oportuno, aparece como pressuposto de intervenções transformadoras radicais. Diz o autor:

O elemento decisivo de cada situação é a força permanentemente organizada e há muito tempo preparada, que se pode fazer avançar quando se julga que uma situação é favorável (e só é favorável na medida em que esta força exista e seja dotada de ardor combativo). Por isso, a tarefa essencial consiste em dedicar-se de modo sistemático e paciente a formar esta força, desenvolvêla, torná-la cada vez mais homogênea, compacta e consciente de si (Gramsci, 2014, p. 46).

O ecossocialismo sob influência trabalhista poderia alegar que é isso que ele faz, e que é por isso que rejeita prontamente qualquer tipo de discurso que seja avaliado como desmobilizador. É possível demonstrar, contudo, que esse definitivamente não é o caso. Primeiro: tal como se encontra, essa força é dramaticamente mal preparada para as exigências dos desafios/conflitos ambientais, sequer os conhece adequadamente. As linhas mestras do seu agir e das suas interpretações são profundamente antiecológicas, por demandar a reprodução de uma lógica antagônica à coevolução sustentável entre sociedade e natureza. Segundo: não há ardor combativo, se entendemos esse ardor como disposição para uma atuação disruptiva, que rompa, inclusive, com fundamentos materiais consagrados de seu próprio cotidiano, por exemplo, o emprego. Há apenas um ardor combativo, empobrecido e vulgar, de demonstrar descontentamento e fazer uso dos canais da pequena política. Terceiro: se é que se pode falar, de fato, de um ardor, de uma subjetividade coletiva inflamada, ele apresenta traços profundamente conservadores, que se voltam à promoção do emprego, da economia nacional, do crescimento econômico, da competitividade externa, da diversificação da pauta de exportações, da inovação etc.

A afirmação de Gramsci citada acima sucede um longo trecho em que o autor discute a inocuidade teórica e prática da referência genérica a "relações de força favoráveis" ou desfavoráveis, frequentemente encontrada nas "narrações históricas". O mesmo tipo de fórmula vazia é encontrado com facilidade na perspectiva aqui criticada, e Williams (2010, p. 149) talvez seja o autor que a expressa (em diversos momentos de sua obra) da maneira mais crua e direta: "Em última análise, a medida em que obtemos uma mudança positiva dependerá do equilíbrio de forças de classes - quanta pressão nosso lado pode trazer para essas questões versus as corporações e grupos de interesses".

Outra vez, Gramsci nos ajuda a ver através da cortina de fumaça quando sublinha que as relações de força podem de fato encontrar um "equilíbrio de compromisso" em que o "grupo dirigente" faz sacrifícios de natureza "econômico-corporativa". No mesmo fôlego, porém, ressalta que "é indubitável que tais sacrifícios e tal compromisso não podem envolver o essencial, dado que, se a hegemonia é ético-política, não pode deixar de ser também econômica, não pode deixar de ter seu fundamento na função decisiva que o grupo dirigente exerce no núcleo decisivo da atividade econômica" (Gramsci, 2014, p. 49; ênfase adicionada).

Aplicando este insight ao nosso problema, tem-se que, se é possível demonstrar teoricamente (e apoiar essa demonstração com uma vasta coleção de evidências empíricas) que o capital é completamente incapaz de conviver com uma redução absoluta da sua demanda material sobre o planeta, não há porque ter a expectativa de que a luta política introduza na realidade uma real diminuição (ou mesmo contenção) do nosso impacto ecológico e climático sem sequer pretender subverter completamente a lógica e as estruturas vigentes. Dito de outra maneira, as eventuais 
vitórias das lutas cujo horizonte se limita a pressionar o Estado e as "corporações" não podem envolver o essencial. Sendo assim, do ponto de vista ecológico e climático, as lutas, enquanto permanecerem enclausuradas nessa fórmula, não podem escapar ao seguinte dilema: por um lado, para serem viáveis, precisam ser ineficazes quanto ao essencial; por outro, se pretenderem ser eficazes, tornam-se inviáveis politicamente, a não ser que assumam caráter conscientemente disruptivo.

Parafraseando Lukács (2013, p. 96), é sintoma do caráter conservador do tipo de mobilização vigente que a pauta ambiental seja, quando muito, incorporada como uma espécie de anexo ad hoc, mesmo o nível concreto de desenvolvimento das ciências naturais permitindo uma leitura muito mais profunda e acurada de nossa condição ambiental (e, especialmente, climática) dramática.

Até nos textos ecossocialistas, as melhores versões desse tipo de enquadramento, a prioridade ontológica do ser natural sobre o ser social é completamente negligenciada. Toma-se o mundo natural como uma espécie de dimensão à parte e inerte da realidade (i.e. sem dinâmica própria), que no momento é vilipendiada e destruída pela ação do capital, mas que a qualquer hora pode ser apropriada por uma lógica mais ecologicamente racional e ser "gentil e cautelosamente guiada [...] em direções cuidadosamente escolhidas" (Burkett, 1999, p. 225). Vale também aqui, portanto, o que Lukács (2013, p. 100) afirma sobre o idealismo:

são apenas consideradas as formas da práxis social que se acham mais afastadas do metabolismo da sociedade com a natureza, e não só não se presta atenção às mediações, frequentemente muito complexas, que as vinculam às suas formas originárias, mas até mesmo se constroem antíteses entre estas e as formas desenvolvidas. Desse modo, [...] a especificidade do ser social desaparece por completo; é construída, artificialmente, uma esfera desprovida de raízes do dever-ser [...], que em seguida é posta em confronto com um - presumido - ser meramente natural do homem [...].

Essa é a manifestação mais acabada do que denominamos, no título desse trabalho, de voluntarismo geológico, que assume uma indefinida flexibilidade do mundo natural diante de nossas finalidades, de nosso gênio criativo, de nossa capacidade de organização e luta etc. Isso, mesmo quando já se identifica a emergência de processos de transformação biogeoquímica abrupta do planeta sem precedentes na história de nossa espécie. O idílico controle consciente, gentil e harmonioso de nosso metabolismo com a natureza é, neste momento e por muito tempo, irrealizável. E "não sendo realizável, se reduz a um fato de consciência que se tornou impotente diante da natureza" (Lukács, 2013, p. 55).

Não proponho, como alternativa a esse voluntarismo geológico, uma espécie de materialismo naturalista vulgar que afirma uma predominância abstrata e absolutamente inflexível das causalidades espontâneas do mundo natural sobre nossa capacidade de converte-las em causalidades postas, a serviço de nossas necessidades. Proponho, de fato, que o planeta em acelerada transformação estreita, também muito rapidamente, nosso "espaço de ação das alternativas concretas". Em outros termos, não se trata de sustentar que nada pode ser feito. Trata-se de afirmar que o conjunto daquilo que pode ser feito com sucesso se modifica de maneira substancial.

Em termos de finalidades coletivamente postas, certamente nenhuma supera em complexidade a finalidade de transformar profundamente o tecido social e a lógica fundamental que o preside. Tal complexidade sem paralelo é ainda agravada quando a humanidade e sua ambição 
emancipatória se depara com uma realidade natural crescentemente hostil à vida orgânica desenvolvida/complexa e, obviamente, à própria vida humana. Não há nenhuma trajetória possível para uma mobilização bem-sucedida que não envolva a consideração explícita, consciente e rigorosa de toda a evidência climática disponível e de todo o conjunto do melhor conhecimento científico a seu respeito. Não levar em conta os claros prognósticos do conhecimento disponível com a alegação de que esse conhecimento é incompleto ou desmobilizador, é uma postura indefensável em qualquer tipo de perspectiva transformadora que se pretenda materialista.

Aproveitando o que diz Gramsci, em outro contexto (mas que se aplica aqui perfeitamente):

se o erro é grave na historiografia, mais grave ainda se torna na arte política, quando se trata não de reconstruir a história passada, mas de construir a história presente e futura: os próprios desejos e as próprias paixões baixas e imediatas constituem a causa do erro, na medida em que substituem a análise objetiva e imparcial e que isto se verifica não como "meio" consciente para estimular à ação, mas como autoengano.

Creio estar suficientemente claro que a reflexão que procurei avançar não propõe o abandono da ação coletiva e organizada em favor de práticas individuais motivadas por desespero, depressão, hedonismo ou paranoia sobrevivencialista. Defendo, ao contrário, a urgência de uma reformulação profunda das modalidades de ação coletiva e das finalidades a que estão predicadas. A seção conclusiva do artigo se volta a esse problema.

\section{Considerações finais: ainda resta alternativa?}

Ainda resta alternativa.

Ninguém será capaz de afirmar categoricamente que o futuro ecossocialista está definitivamente fora de nosso alcance. Mas existem evidências contundentes de que o foco de nossos esforços deve ser direcionado a estratégias de adaptação profunda e a reunir as condições mínimas para a sobrevivência da espécie. Nessa mesma linha, há evidências mais do que suficientes de que isso deve ser feito imediatamente e com um senso de urgência que abandone em definitivo a luta pulverizada, autoindulgente e de ambições medíocres. Não se trata de afirmar que a via revolucionária é preferível ou superior a outras disponíveis. Trata-se de afirmar que ela é a única via ainda em aberto com algum potencial para evitar nosso próprio desaparecimento.

No curto prazo testemunharemos, muito provavelmente, a transformação de vastíssimas regiões do planeta em zonas inabitáveis, processos migratórios sem precedentes (em termos de escala, velocidade e toda a violência produzida em seu rastro), insegurança alimentar sem precedentes e declínio populacional agudo, dramático e também sem precedentes. Qualquer mobilização coletiva orientada a uma transformação social conscientemente desejada irá se deparar com essa realidade em um futuro terrivelmente próximo e terá que se demonstrar capaz de nela encontrar as condições para garantir a sobrevivência da espécie e, eventualmente, num futuro ainda inacessível à consciência, fazê-la prosperar.

Mesmo no ideário conservador, que prefere naufragar abraçado à sociabilidade do capital a cogitar qualquer possibilidade de uma sociedade pós-capitalista, essa consciência de urgência se instalou. Em discurso de setembro de 2018, o secretário-geral da ONU, António Guterrez (2018; 
ênfase adicionada), declarou com todas as letras que o risco que enfrentamos é existencial (tal como todas as informações que cotejamos nos leva a concluir):

Eu chamei vocês aqui para soar o alarme. A mudança climática é a questão que define nosso tempo - e estamos em um momento decisivo. Nós enfrentamos uma ameaça existencial direta. A mudança climática está se movendo mais rápido do que nós - e sua velocidade provocou um estrondo sonoro de SOS em todo o mundo. [...] Que não haja dúvidas sobre a urgência da crise. [...] Em maio deste ano, a Organização Meteorológica Mundial relatou que o planeta alcançou mais um marco sombrio: a maior média mensal de níveis de dióxido de carbono já registrada. Quatrocentas partes por milhão há muito são vistas como um limiar crítico. Mas agora superamos 411 partes por milhão e as concentrações continuam a subir. Esta é a maior concentração em 3 milhões de anos. [...] Não há mais tempo a perder. Como mostra a ferocidade dos incêndios e ondas de calor deste verão, o mundo está mudando diante dos nossos olhos. Estamos nos dirigindo para a beira do abismo.

Diante da demonstração clara de reconhecimento da gravidade da situação, não é um salto da imaginação esperar que esse mesmo campo conservador mobilizará, muito pragmaticamente, todos os recursos ao seu dispor para proteger ou se apropriar de quaisquer condições materiais de suporte à vida que restem disponíveis. O rol de movimentações dessa natureza vai desde a construção de comunidades-bunker pelos super-ricos até, possivelmente, ações militares (porém, nesse caso, sem a fachada civilizacional da mediação de organismos supranacionais como a ONU). Creio que vale aqui a mesma intuição que Gramsci (2014, p. 61) apresenta para o plano estritamente social, quando aponta que a

crise cria situações imediatas perigosas, já que os diversos estratos da população não possuem a mesma capacidade de se orientar rapidamente e de se reorganizar com o mesmo ritmo. A classe dirigente tradicional, que tem um numeroso pessoal treinado, muda homens e programas e retoma do controle que lhe fugia com uma rapidez maior do que a que se verifica entre as classes subalternas.

Logo na sequência, o mesmo autor nos deixa entrever o terreno de possibilidades para nossa própria atuação:

A unificação das tropas de muitos partidos sob a bandeira de um único partido, que representa melhor e sintetiza as necessidades de toda a classe, é um fenômeno orgânico e normal, ainda que seu ritmo seja muito rápido e quase fulminante em relação aos tempos tranquilos: representa a fusão de todo um grupo social sob uma só direção, considerada a única capaz de resolver um problema vital dominante e de afastar um perigo mortal (Gramsci, 2014, p.61).

Depois de tudo que foi discutido, sustento que cabe aos ecossocialistas - apoiados em Marx, mas também em um diagnóstico solidamente fundado no conhecimento científico sobre as mudanças climáticas - se colocar como essa direção capaz de resolver tal problema vital. E, para isso, enunciar sem filtros, com o maior rigor e precisão possíveis, o conteúdo grave de nossa situação, é fundamental. A demonstração (e tomada de consciência) rigorosa do iminente colapso ambiental e dos riscos bastante reais e elevados de aniquilação da espécie pode não vir a ser o catalizador do tipo de síntese da qual fala Gramsci. Creio, porém, que certamente não atua contra sua realização. 
Finalizando a questão a partir de outro enquadramento, a última coisa que podemos aceitar é que justamente o campo de pretensões revolucionárias se situe, em seu diagnóstico e em sua disposição a agir, aquém do campo conservador. Isso, precisamente quando a via revolucionária coloca-se como a única via com potencial para nos garantir mais tempo e, com alguma sorte (pois o acaso é elemento objetivo da realidade), garantir as condições para que a humanidade possa florescer em um planeta crescentemente instável.

Bibliografia

ARISTÓTELES. Metafísica. São Paulo: Edições Loyola, 2002.

BERKELEY EARTH. Summary of findings. Retrieved from berkeleyearth.org: http://berkeleyearth.org/summary-of-findings/. 2019.

BROOKES, L. Energy efficiency fallacies revisited. Energy Policy, v. 28, n. 6-7, 2000.

BURKETT, P. Marx and nature: a red and green perspective. New York: St. Martin's Press, 1999.

BURKETT, P. Two stages of ecosocialism? International Journal of Political Economy, v. 35, n. 3, 2006.

ENGELS, F. A dialética da natureza. São Paulo: Paz e Terra, 1979.

FOSTER, J. B. A ecologia de Marx. Rio de Janeiro: Civilização Brasileira, 2005.

GRAMSCI, A. Cadernos do cárcere. Rio de Janeiro: Civilização Brasileira, 2014. v. 3.

GUTERRES, A. Remarks on climate change (ONU, Ed.) Retrieved from United Nations Secretarygeneral's speeches: https://www.un.org/sg/en/content/sg/speeches/2018-09-10/remarks-climatechange. 10 set. 2018.

HANSEN, J. Scientific reticence and sea level rise. Environmental Research Letters, 2, 2007.

IPCC. Climate change 2007: synthesis report. Genebra, 2007.

IPCC. Climate change 2014: synthesis report. Genebra, 2014.

IPCC. Global warming of $1.5 \mathrm{C}$ : an IPCC special report on the impacts of global warming of $1.5^{\circ} \mathrm{C}$ above pre-industrial levels. Genebra, 2018.

LOVELOCK, J. The anishing face of Gaia: a final warning. London: Penguin Books, 2009.

LÖWY, M. What is ecosocialism? Capitalism, Nature, Socialism, v. 16, n. 2, 2005.

LÖWY, M. Mensagem ecológica ao camarada Marx. Cadernos Cemarx, 11, 2018.

LUKÁCS, G. Para uma ontologia do ser social I. São Paulo: Boitempo, 2012.

LUKÁCS, G. Para um ontologia do ser social II. São Paulo: Boitempo, 2013.

MARX, K. Grundrisse. São Paulo: Boitempo, 2011.

MARX, K. O Capital. São Paulo: Boitempo, 2013. v. I.

MARX, K. O Capital. São Paulo: Boitempo, 2017. v. III. 
MARX, K.; ENGELS, F. Collected works. New York: International Publishers, 1976. v. 6.

MARX, K.; ENGELS, F. A ideologia alemã. São Paulo: Boitempo, 2007.

MEDEIROS, J. L. A economia diante do horror econômico. Niterói: Eduff, 2013.

MEDEIROS, J. L.; LEITE, L. Em busca do elo perdido: sobre a gênese dialética da categoria capital. In: ENCONTRO NACIONAL DE ECONOMIA POLÍTICA, 21, São Bernardo do Campo: SEP. 2016.

MEDEIROS, J. L.; SÁ BARRETO, E. Lukáscs e Marx contra o “ecologismo acrítico”: por uma ética ambiental materialista. Economia e Sociedade, Campinas, v. 22, n. 2 (48), p. 317-333, ago. 2013.

NASA. Global climate change: vital signs of the planet. Retrieved from: https://climate.nasa.gov/vital-signs/global-temperature/. 2019.

POSTONE, M. Time, labor, and social domination. Cambridge: Cambridge University Press, 2003.

RAHMSTORF, et al. Recent climate observations compared to projections. Science, v. 316, n. 5825, 2007.

SÁ BARRETO, E. Marxs contra o otimismo tecnológico: economia "imaterial" desmistificada e desdobramentos para as questões ambientais. Nova Economia, v. 26, n. 1, 2014a.

SÁ BARRETO, E. As múltiplas dimensões da exigência imposta à esfera do consumo pela dinâmica do capital: elementos para o debate ambiental. Revista da Sociedade Brasileira de Economia Política, $37,2014 b$.

SÁ BARRETO, E. O capital na estufa: para a crítica da economia das mudanças climáticas. Rio de Janeiro: Consequência, 2018.

SABADINI, M. D. S. Especulação financeira e capitalismo contemporâneo: uma proposição teórica a partir de Marx. Economia e Sociedade, Campinas, v. 22, n. 3 (49), 2013.

SPRATT, D.; DUNLOP, I. What lies Beneath: the understatement of existential climate risk. Melbourne: Breakthrough, 2018.

STEFFEN, et al. Trajectories of the Earth System in the Anthropocene. PNAS, v. 115, n. 33, 2018.

STERN, N. The economics of climate change: the Stern review. Cambridge: Cambridge University Press, 2007.

USGCRP. Impacts, risks, and adaptation in the United States: Fourth National Climate Assessment, Volume II: Report-in-Brief. Washington, 2018.

WILLIAMS, C. Ecology and socialism. Chicago: Haymarket Books, 2010. 